НАУКОВИЙ ВІСНИК

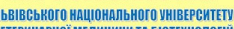

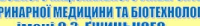
ientific Scientific messenger of Livi National University of
Veterinary Medicine and Biotechnologies

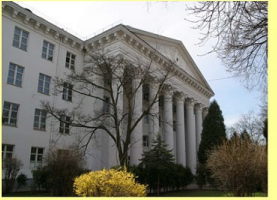

СЕРЯЯ "ЕКОНОМІчН НАУК

Том 22 № 95 2020
Науковий вісник Аьвівського національного університету ветеринарної медицини та біотехнологій імені С.3. Гжицького. Серія: Економічні науки

\author{
Scientific Messenger of Lviv National University \\ of Veterinary Medicine and Biotechnologies. \\ Series: Economical Sciences
}

ISSN 2519-2701 print

UDC 330.3.341.1:631.1

\title{
The problems of investment support of innovative development of agriculture
}

\author{
N. Radukh
}

Stepan Gzhytskyi National University of Veterinary Medicine and Biotechnologies Lviv, Ukraine

Article info

Received 09.09.2020

Received in revised form 12.10 .2020

Accepted 13.10.2020

Stepan Gzhytskyi National University of Veterinary Medicine and Biotechnologies Lviv,

Pekarska Str., 50, Lviv, 79010, Ukraine.

Tel.: +38-097-711-98-34

E-mail:nraduh@ukr.net
Radukh, N. (2020). The problems of investment support of innovative development of agriculture. Scientific Messenger of Lviv National University of Veterinary Medicine and Biotechnologies. Series: Economical Sciences, 22(95), 52-57. doi: 10.32718/nvlvet-e9509

The article examines the main problems facing the development of competitive agriculture, given the dynamism of investment in the industry and investment in the current environment of increasing globalization, as the introduction of innovative products is the basis for effective development of the enterprise, region and country. The analysis of the main indicators that characterize the level of investment support of enterprises of Lviv region, in particular the volume of capital investments and the volume of foreign direct investment. The volumes of agricultural output in enterprises and households of the population, and, accordingly, the possibility of attracting investment by these categories of producers are considered. The main problems of agricultural production are characterized and the directions of intensification of investment and innovation activity are offered, taking into account the support of the state, foreign economic potential of the region, its border location and export-oriented production. Innovative development of agriculture, expanding the ways of its investment are among the factors that play a crucial role in ensuring the balanced development of the region, building strategic prospects for its economic growth, identifying internal problems and obstacles to this process, and adequately assessing the potential of local resource levels. It is considered that the priority in today's conditions is the introduction of technologies for environmentally friendly cultivation of crops and the development of organic production, development of infrastructure for storage and distribution of agricultural products by attracting investment projects. It is important for agricultural producers to adapt to international food quality and safety standards and to produce agricultural products that meet EU requirements and standards. The model of strategic goals of innovative development of agriculture is offered, which aims to promote effective optimization of agricultural production, development of production infrastructure on the basis of state assistance and support, taking into account the stimulation of investment projects and attracting foreign funds.

Key words: investment, foreign direct investment, capital investment, agriculture, competitiveness.

\section{Проблеми інвестиційного забезпечення інноваційного розвитку сільського господарства}

\author{
Н. Б. Радух
}

Львівський національний університет ветеринарної медицини та біотехнологій імені С. 3. Гюицького, м. Львів, Україна

У статті досліджуються основні проблеми, щуо стоять на шляху розвитку конкурентоспроможного сільського господарства, враховуючи динамізм показників інвестування у галузь та інвестиційного забезпечення у сучасних умовах посилення впливу глобалізаційних процесів, оскільки впровадження інноваційних продуктів є базисом ефективного розвитку підприємства, регіону та країни в цілому. Проведено аналіз основних показників, щуо характеризують рівень інвестиційного забезпечення підприємств Львівської області, зокрема обсяг капітальних інвестицій та обсяг прямих іноземних інвестицій. Розглядаються обсяги випуску сільськогосподарської продукиї у підприємствах та господарствах населення, та відповідно можсливості до залучення інвестицій ичии категоріями виробників. Охарактеризовано основні проблеми сільськогосподарського виробництва та запропоновано напрями активі- 
зації інвестиційно-інноваційної діяльності з врахуванням підтримки держави, зовнішньоекономічного потенціалу регіону, його прикордонного розташування та експортоорієнтованого виробництва. Інноваційний розвиток сільського господарства, розиирення шляхів його інвестиційного забезпечення є одними з факторів, щуо відіграють вирішальну роль у забезпеченні збалансованого розвитку регіону, побудові стратегічних перспектив його економічного зростання, визначення внутрішніх проблем та перешкод, щчо гальмують цей процес, та адекватна оиінка потенціалу наявних на місцевому рівні ресурсів. Розглядається, шчо пріоритетом в умовах сьогодення є впровадження технологій екологічно чистого вирощування сільськогосподарських культур і розвиток органічного виробництва, розвиток інфраструктури зберігання та дистрибуції сільгосппродукиії за рахунок залучення інвестиційних проектів. Актуальною є адаптація сільгоспвиробників до міжнародних стандартів якості та безпеки харчових продуктів і виробництво сільськогосподарської продукиї, щчо відповідає вимогам і стандартам ЄС. Запропоновано модель стратегічних иілей інноваційного розвитку сільського господарства, яка має на меті сприяти ефективній оптимізації виробництва сільськогосподарської продукиї, розвитку виробничої інфраструктури на основі державного сприяння та підтримки, враховуючи стимулювання інвестиційних проектів і залучення іноземних коштів.

Ключові слова: інвестицї, прямі іноземні інвестициї, капітальні інвестицї, сільське господарство, конкурентоспроможність.

\section{Вступ}

Сучасну ринкову економіку в умовах інтеграційних перетворень важко уявити без інвестицій, які $є$ ключовим визначником всієї економічної політики, а від їх ефективності залежить стан виробництва, рівень технічного озброєння підприємств, можливості структурної перебудови економіки, розв'язання соціальних та екологічних проблем. Інвестиції є основою розвитку підприємств, окремих галузей та економіки в цілому. Особливо важлива роль при цьому належить іноземному капіталу, який надає можливості для розвитку нових проектів, отримання сучасних технологій i обладнання, запровадження нових маркетингових стратегій та освоєння нових ринків збуту. Іноземне фінансування особливо важливе в умовах дефіциту внутрішніх фінансвових ресурсів, які потрібні для активізації інвестиційної діяльності та проведення структурної перебудови економіки суб'єктів господарювання. Враховуючи різноманітні чинники, регіону ще не вдалося сповна реалізувати свій інвестиційний потенціал, що суттєво стримує розвиток бізнесу на Львівщині, який є основним реципієнтом інвестиційних ресурсів (Main Department of Statistics in Lviv Region, 2020).

Актуальність теми. Виокремлення основних проблем в інвестиційному забезпеченні інноваційного розвитку сільськогосподарського виробництва сприятиме можливості розробки та впровадження ефективних заходів щодо інноваційно-інвестиційного розвитку сільського господарства регіону та виведення його на відносно новий етап функціонування.

У сучасних наукових дослідженнях багато питань зосереджено на вивченні інвестиційних процесів, зокрема такими вітчизняними науковцями як: В. В. Крук, Т. В. Майорова, О. Я. Макаренко, Я. В. Шевчук, I. І. Чуницька та інші. Однак не всі аспекти цієї багатогранної проблеми вирішені, а багато положень мають дискурсивний характер і потребують аналізу, обговорення та подальшого вирішення, раніше нерозв'язаних проблем.

Мета і завдання дослідження. Мета даної публікації полягає в аналізі динамізму інноваційноінвестиційних процесів у сільському господарстві Львівської області у сучасних інтеграційних умовах.

Для досягнення поставленої мети потрібно розв'язати такі основні завдання:

- оцінити стан інвестиційного забезпечення підприємств регіону;
- проаналізувати інвестиційні можливості та визначити основні джерела здійснення інвестицій;

- виділити перспективні напрями посилення інвестиційно забезпечення інноваційного розвитку сільськогосподарських підприємств Львівської області.

\section{Матеріал і методи досліджень}

Під час дослідження використано такі наукові методи: абстрактно-логічний, зокрема його прийоми узагальнення, аналогії, аналізу та синтезу, індукції та дедукції (для формулювання теоретичних узагальнень результатів дослідження, формулювання висновків і пропозицій); економіко-статистичний, зокрема його прийоми: порівняння (для співставлення фактичних даних звітного року з даними попередніх періодів).

\section{Результати та їх обговорення}

Сільське господарство Львівської області є важливою частиною економіки. У 2018 р. продукція сільського господарства Львівської області становила 10189,9 млн. грн і збільшилась порівняно з 2017 р. на $3,8 \%$. Частка господарств населення у загальному обсязі виробництва становила 58,8\% (у 2017 р. $61,1 \%$ ), ними вироблено 55,4 \% продукції рослинництва і 64,5 \% - тваринництва. Частка продукції рослинництва у загальному обсязі сільськогосподарського виробництва склала 63,6 \%, продукції тваринництва - 36,4\%. Порівняно 32017 р. у рослинництві спостерігалося зростання обсягів виробництва на $4,3 \%$, у тому числі у підприємствах - на 8,9\%, у господарствах населення - на 0,9\%. У тваринництві відбулося зростання обсягів виробництва на 2,8 \%, у тому числі у сільськогосподарських підприємствах зростання на $12,9 \%$, у господарствах населення зменшення на 2,0 \%. У 2018 р. за обсягами виготовленої сільськогосподарської продукції підприємствами Львівщина зайняла лише 17 місце серед інших регіонів України, тоді як за обсягами виготовленої продукції господарствами населення - 5 місце у порівнянні з іншими регіонами (за обсягами продукції рослинництва - 7 місце та 3 позицію за обсягами продукції тваринництва) (Main Department of Statistics in Lviv Region, 2019). Такий дисонанс спричинений насамперед характерним розподілом населення (вища частка сільського населення, ніж в середньому по Україні), що впливає i на співвідношення типів 
суб“єктів, що здійснюють виробництво сільськогосподарської продукції: 61,2 \% продукції рослинництва та 72,3 \% продукції тваринництва в області виробляють господарства населення. Разом 3 тим, існують загрозливі тенденції спаду обсягів виробництва продукції тваринництва, що за окремими позиціями вже сьогодні не відповідають актуальним споживчим потребам області, а також характеризуються збитковістю, внаслідок чого відсутніми є стимули для їх розвитку (Main Department of Statistics in Lviv Region, 2019).

Виробництво сільськогосподарської продукції здійснюють понад 200 тис. домашніх господарств та 1,4 тис. сільськогосподарських підприємств (Main Department of Statistics in Lviv Region, 2020). Впродовж останніх років структура сільськогосподарського виробництва характеризується значними змінами, які формують зміну якості життя населення сільських територій. Ціни на сільськогосподарські товари наближаються до європейських, тоді як сільськогосподарське виробництво не стає ефективнішим i прибутковішим. Деякі види продукції сільського господарства $є$ низькорентабельними чи збитковими. Сільськогосподарські підприємства, особливо малі та середні мають проблеми щодо впровадження іннова-

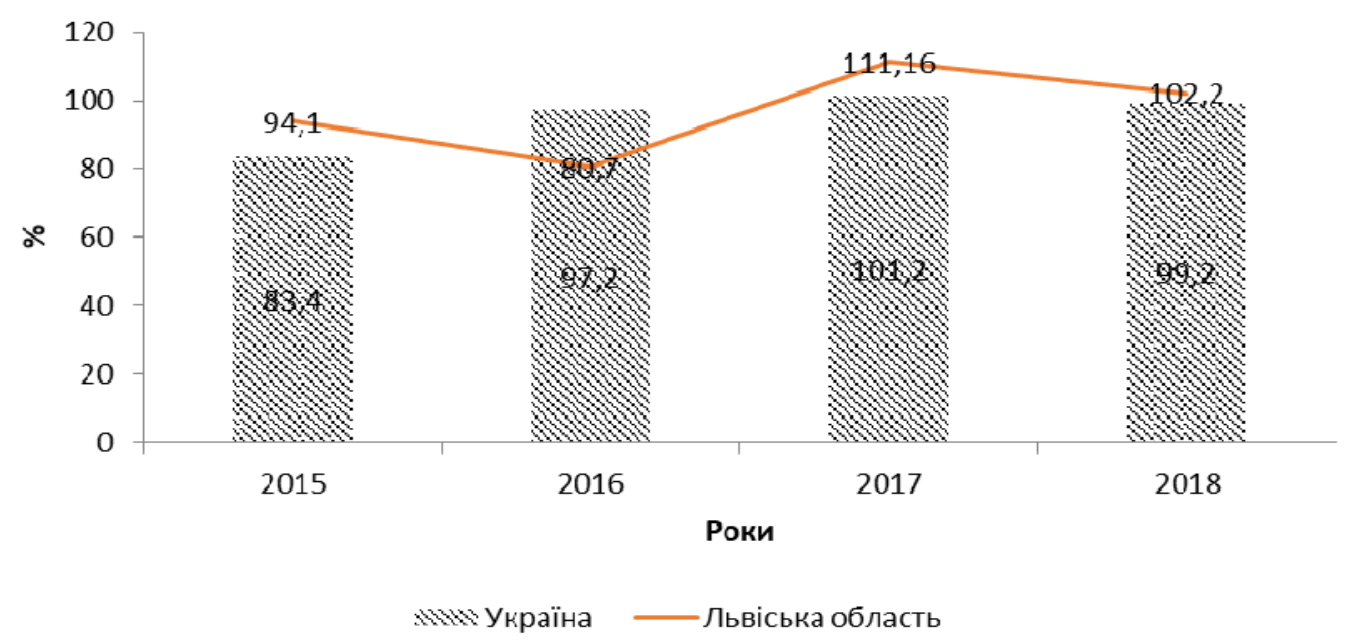

Рис. 1. Темпи зміни обсягів прямих іноземних інвестицій у сільському господарстві, \% Джерело: побудовано автором на основі даних (Main Department of Statistics in Lviv Region, 2019; 2020)

Прямі іноземні інвестиції відбуваються через пряме збільшення капіталу нерезидентів за рахунок їх внесків до статутного капіталу підприємства або укладення договорів про спільну інвестиційну діяльність. Така форма інвестиційного забезпечення є доступною для великих сільськогосподарських товаровиробників, і практично є недієва для малого і середнього бізнесу.

Потоки прямих іноземних інвестицій спрямовуються переважно не у виробництво товарів, а у сфери обслуговування, транспортування та розподілу товарів і послуг. Такий галузевий розподіл прямих іноземних інвестицій відбувається як наслідок бізнесових стратегій іноземних інвесторів. Як підтверджують наукові дослідження, підприємства, які залучають прямі іноземні інвестиції показують вищу продуктив- цій у виробництво. Виробничий потенціал аграрного сектора Львівської області є потужним, проте використовується не у повній мірі. Створення сприятливих умов для ведення галузі забезпечить продовольчу безпеку області та нарощення експортного потенціалу.

Головними проблемами інноваційного розвитку сільського господарства, а значить і забезпечення відповідного рівня конкурентоспроможності у Львівській області $\epsilon$ : низький рівень матеріальнотехнічного забезпечення сільськогосподарського виробництва, високий ступінь зносу основних засобів; низький рівень оплати праці; висока концентрація виробництва окремих видів сільськогосподарської продукції у господарствах населення, рівень фінансового забезпечення яких не дає можливості виробляти конкурентоспроможну продукцію відповідної якості; скорочення обсягів виробництва у тваринництві; незадовільне інфраструктурне забезпечення сільських територій.

Сучасний рівень прямих іноземних інвестицій не забезпечує передумов економічного зростання сільського господарства, а на інвестиційну привабливість значно впливають умови господарювання створені державою (рис. 1). 


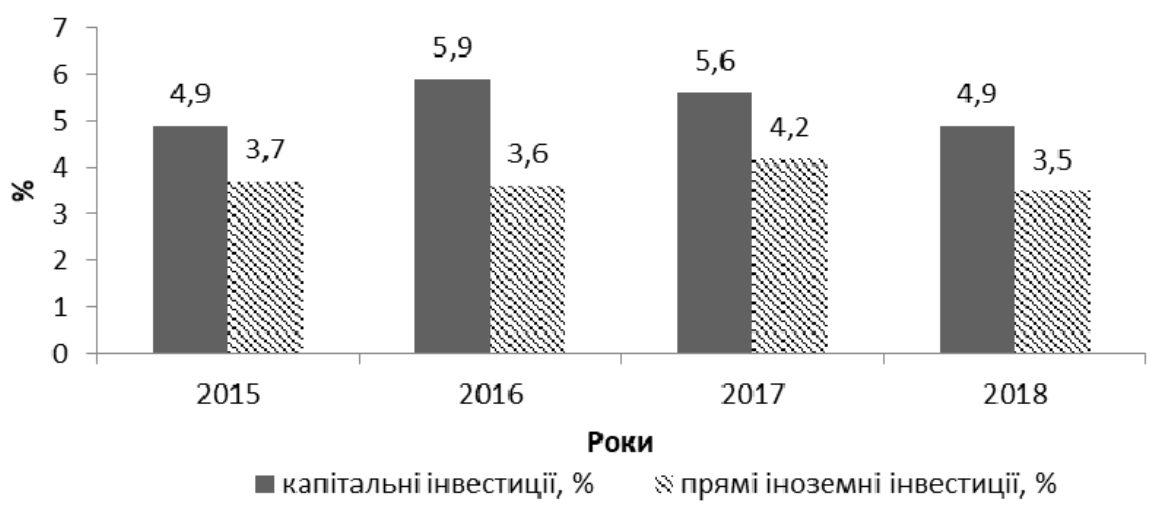

Рис. 2. Темпи зміни обсягів інвестицій у сільське господарство Львівської області, \% Джерело: побудовано автором на основі даних (Main Department of Statistics in Lviv Region, 2019; 2020)

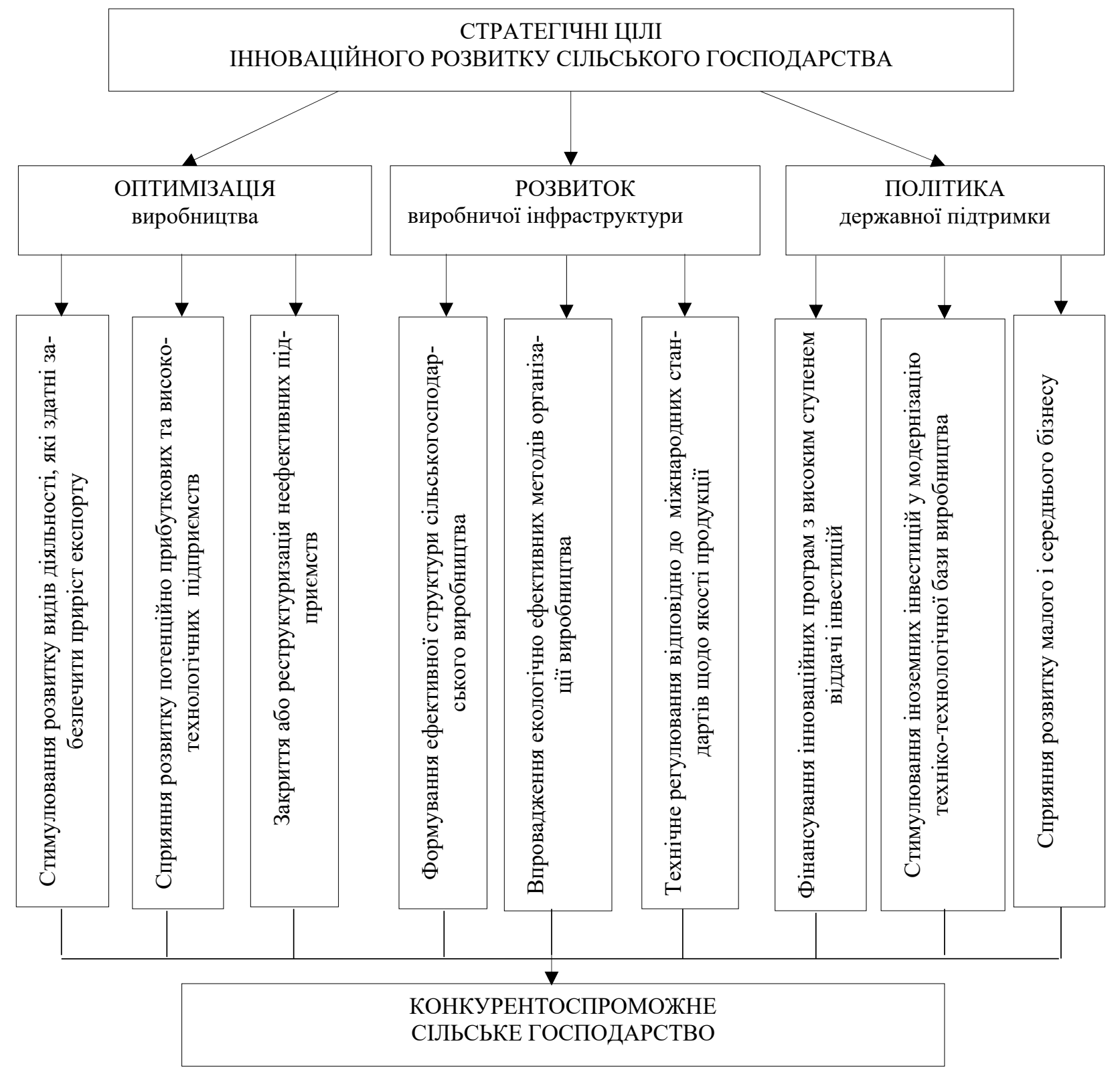

Джерело: побудовано автором

Рис. 3. Цілі інноваційного розвитку сільського господарства 
Причинами зниження рівня інвестування є економічна та політична нестабільність, що призводить до виникнення процесів, які не підлягають регулюванню: військові дії на Сході України, стагнація економіки, девальвація та інфляція, зниження рівня споживання. Дієвими інструментами зростання капітальних інвестицій в сільське господарство є насамперед: забезпечення сприятливих макрофінансових умов для інвестиційної діяльності та підвищення ефективності державного інвестування; розширення обсягів кредитного забезпечення; удосконалення фінансового законодавства у сфері інвестицій; інтеграції національного фінансового ринку зі світовими ринками капіталу. Однак ефективна робота даних інструментів можлива при розробці механізму правового регулювання на макро- та мікрорівнях, яке, може забезпечити необхідні перетворення за допомогою системи страхування (Rozhenko, 2020).

Ключовими проблемами розвитку сільського господарства є: відсутність власної інфраструктури первинної переробки, зберігання, транспортування, сільськогосподарської продукції і не можуть брати участь на організованому ринку 3 високими вимогами до безпечності та якості продукції; втрачені позиції малого та середнього сільськогосподарського виробника на організованому ринку сільськогосподарської продукції, які не покриваються за рахунок надходжень від вільного продажу на продовольчих ринках; висока ресурсо- та енергоємність виробництва сільськогосподарської продукції; нерозвинутість складових інфраструктури аграрного ринку; збільшення концентрації земельних ресурсів інтегрованими структурами; низька громадянська ініціативність та підприємницька активність сільського населення; недостатній рівень налагодженості системи та механізмів зворотного зв'язку між владою, підприємницькими структурами і сільськими громадами.

Вирішення вищезгаданих проблем дозволить покращити ефективність виробництва сільськогосподарської продукції; підвищити доходи сільськогосподарських товаровиробників; створити нові робочі місця; укрупнювати господарську діяльності малих виробників; розвивати інформаційну та маркетингову інфраструктуру аграрного ринку регіону.

Для досягнення інноваційного розвитку сільського господарства необхідно дотримуватися стратегічних цілей інноваційного розвитку (рис. 3) і розвивати сільську кооперацію, зокрема через створення сімейних молочних ферм, асоціацій виробників однотипних видів сільськогосподарської продукції за участю малих, середніх та великих сільськогосподарських підприємств, сприяти придбанню інноваційного обладнання для зберігання та первинної переробки продукції.

Розвиток інформаційної та маркетингової інфраструктури аграрного ринку регіону необхідно втілювати через створення електронних торгових платформ для поширення інформації і реалізації продукції широкому загалу населення. Пріоритетним у сучасних умовах є впровадження технологій екологічно чистого вирощування сільськогосподарських культур і розвиток органічного виробництва, розвиток інфра- структури зберігання та дистрибуції сільгосппродукції за рахунок залучення інвестиційних проектів. Актуальною для зростання конкурентоспроможності сільського господарства є адаптація сільгоспвиробників до міжнародних стандартів якості та безпеки харчових продуктів і виробництво сільськогосподарської продукції, що відповідає вимогам і стандартам СС, а також збереження, відтворення та підвищення родючості грунтів, дотримання правил сівозмін. Досягнення такого роду завдань не можливе без участі держави, в особі органів місцевого самоврядування та об'єднаних територіальних громад.

\section{Висновки}

Формування політики інвестиційного забезпечення можливе через створення сприятливого регуляторного середовища, якісний відбір на конкурсних засадах регіональних інвестиційних проектів, залучення міжнародниих інвестиційних коштів в проекти щодо модернізації матеріально-технічного забезпечення підприємств 3 втіленням програм 3 розвитку інновацій, а також підтримка впровадження інновацій у діяльність малих і середніх підприємств, зокрема у селянських (фермерських) господарствах. Важливим при вирішенні проблем сільського господарства може стати розробка і використання механізмів стимулювання до впровадження енерго- та ресурсозберігаючих технологій, альтернативних джерел енергії, екологічно безпечних виробництв та технологій, інновацій у сфері природокористування; сприяння впровадженню систем екологічного управління серед суб'єктів малого та середнього бізнесу.

Перспективи подальиих досліджень. Актуальними продовжують залишатися проблеми інвестиційного забезпечення та обізнаності керівників підприємств щодо можливостей налагодження інноваційного виробництва сільськогосподарської продукції із застосуванням технологій, які зможуть покращити якісний стан навколишнього середовища та ефективніше використовувати природні ресурси у підприємницькій діяльності. Подальші дослідження матимуть на меті дослідження інвестиційних можливостей як на рівні підприємств, так і на рівні територіальних громад. А основними індикаторами для досліджень стану сільського господарства будуть показники обсягів виробництва сільськогосподарської продукції; динаміка доданої вартості у сільськогосподарському виробництві; ефективність та прибутковість сільськогосподарського виробництва; динаміка обсягів експорту сільськогосподарської продукції і рівень зайнятості сільського населення.

\section{References}

Chunyts'ka, I. I., \& Makarenko, O. Ya. (2019). Inozemni investytsii v ekonomiku Ukrainy: suchasnyj stan ta shliakhy pokraschennia investytsijnoho klimatu [Foreign investment in the economy of Ukraine: current status and ways to improve the investment climate], Zbirnyk naukovykh prats' Universytetu derzhavnoi fiskal'noi sluzhby Ukrainy, 1, 246-262. 
doi: 10.33244/2617-5940.1.2019.246-262 (in Ukrainian).

Fedorova, N. Ye., Ohorodnyk, R. P., \& Rusal, V. S. (2020). Inozemne investuvannia V ekonomiku Ukrainy: masshtaby, struktura, perspektyvy [Foreign investment in the economy of Ukraine: scale, structure, prospects]. Naukovyj visnyk Khersons'koho derzhavnoho universytetu, 39, 14-18. doi: 10.32999/ksu2307-8030/2020-39-2 (in Ukrainian).

Main Department of Statistics in Lviv Region (2019). Investytsii u L'vivs'kij oblasti. 2018 r. [Investments in Lviv region. 2018], statistical collection, 83 (in Ukrainian).
Main Department of Statistics in Lviv Region (2019). Sil's'ke hospodarstvo L'vivs'koi oblasti u2018 r [Agriculture of Lviv region. 2018], statistical collection, 172 (in Ukrainian).

Main Department of Statistics in Lviv Region (2020). Investuvannia ekonomiky L'vivs'koi oblasti u 2019 r [Investing in the economy of Lviv region. 2019], analytical report, 16 (in Ukrainian).

Rozhenko, O. V. (2020). Pravove rehuliuvannia strakhuvannia investytsij v Ukraini [Legal regulation of investment insurance in Ukraine]. Pravovyj chasopys Donbasu, 2(71), 89-96. doi: 10.32366/25234269-2020-71-2-89-96 (in Ukrainian). 